\title{
Analisis Manajemen Resiko berbasis ISO 9001:2015 dan ISO 31010:2009 pada Pelayanan Sistem Informasi Akademik "EduManage" di Universitas Setia Budi
}

\author{
Anita Indrasari*1, Adhie Tri Wahyudi ${ }^{2}$ \\ ${ }^{1,2}$ Universitas Setia Budi, Jl. Letjen. Sutoyo, Mojosongo, Surakarta \\ 1,2 Program Studi S1 Teknik Industri \\ e-mail: *11 anita.indrasari@gmail.com, ${ }^{2}$ adhie.wahyudi@gmail.com
}

\begin{abstract}
Abstrak
Teknologi Informasi (TI) dalam hal ini program Edu Manage merupakan aset penting bagi Universitas Setia Budi (USB) dalam penjaminan mutu pelayanan bidang akademik yang harus dikelola secara efektif agar penggunaannya menjadi optimal. Penggunaan IT secara optimal dapat dilakukan dengan melibatkan analisa manajemen resiko. Sasaran mutu Universitas Setia Budi (USB) yang menuntut pencapaian layanan akademik yang prima, dan banyak kasus terjadi berkaitan dengan Edu Manage, seperti: perubahan kebijakan/ aturan akademik berupa penyesuaian kurikulum, berkurangnya staf Sistem Informasi, terhentinya aplikasi karena virus dan hacker menuntut agar pengembangan pelayanan dilakukan berdasar analisa manajemen resiko. Penelitian ini bertujuan untuk memberikan rekomendasi mitigasi risiko TI pada tata kelola layanan Edumanage di USB. Analisa menggunakan pendekatan ISO 9001:2015, ISO 31010:2009 serta menggunakan Failure Mode and Effect Analysis (FMEA) sebagai alat bantunya. Dari hasil penelitian diperoleh 37 resiko yang mungkin terjadi, dengan 13 resiko yang berkategori resiko sedang hingga tinggi, sehingga direkomendasikan untuk mendapatkan prioritas mitigasi. Langkah mitigasi resiko yang direkomendasikan adalah: pengadaan UPS di server dengan kapasitas yang mencukupi dan UPS portabel di setiap node jaringan; Pembuatan SOP Backup, konsistensi pelaksanaan dan sistem controlling; Pembuatan flow chart proses, input KRS untuk mahasiswa, input mata kuliah untuk Kaprogdi yang simpel, jelas dan memudahkan user untuk memahami; Pembuatan SOP pengecekan kelengkapan data di setiap akhir semester; Sosialisasi dan notifikasi jadwal input nilai, KRS mahasiswa dan approval KRS lewat beberapa media (web, wa, dll)
\end{abstract}

Kata kunci — manajemen resiko, teknologi informasi, ISO 9001:2015, ISO 31010:200, FMEA

\section{PENDAHULUAN}

Penerapan Teknologi Informasi (TI) menjadi salah satu unsur penting yang mampu mempercepat kinerja. Dengan daya efektifitas dan efisiensi yang 
ditawarkan, penerapan TI pada suatu organisasi, mendorong keunggulan bersaing dengan kompetitor (Putra, 2015). Pemanfaatan TI yang dikelola dengan baik pada sebuah lembaga pendidikan tinggi, diyakini akan memberikan kemudahan dan efisiensi sistem administrasi (Bagye, 2015). Universitas Setia Budi (USB) merupakan institusi pendidikan tinggi di kota Surakarta yang memiliki tujuan mencetak sumber daya manusia yang unggul. Dalam upaya meningkatkan kinerja dan mutu layanan administrasi akademik, USB memanfaatkan TI, dengan membangun sistem informasi akademik "EduManage". Layanan sistem informasi akademik yang lengkap, akurat, konsisten, tepat waktu, dan relevan merupakan hal yang penting bagi USB untuk menciptakan loyalitas pengguna, meningkatkan efektifitas, dan efisiensi penggunaan sumber daya yang bersifat resource sharing. EduManage merupakan sistem informasi akademik yang dikembangkan oleh USB untuk mempermudah pengolahan data akademik bagi mahasiswa, dosen, tata usaha (TU), ketua program studi dan staf akademik Bagian Administrasi Akademik (BAA).

Peranan TI pada suatu perusahaan menjadi unsur yang sangat penting, namun dalam implementasinya selain nilai manfaat, juga terdapat berbagai risiko (Information Technology Risk) yang dapat mempengaruhi pencapaian sasaran organisasi (Angraini dan Pertiwi, 2017). Penggunaan TI pada proses pengelolaan data EduManage di USB menimbulkan beberapa resiko yang bisa mengakibatkan kelemahan (vulnerabilities) sehingga akan menimbulkan ancaman (threats). Risiko kerusakan sistem dan risiko keamanan data adalah issue utama reliability layanan berbasis IT (Darwis dan Yuniarwati, 2016). Angraini dan Pertiwi, (2017) pada publikasi penelitian resiko di BAPPEDA Pemerintah Provinsi Riau menyebutkan bahwa risiko yang dapat timbul akibat kesalahan penerapan tata kelola TI adalah risiko kehilangan data yang diakibatkan dari tidak adanya cadangan basisdata pada instansi, kerusakan hardware dan infrastruktur pendukung serta kerusakan software. Timbulnya risiko TI pada layanan EduManage tidak selalu dikarenakan mal-fungsi pada komponen hardware, jaringan maupun software. Putra, (2015) dalam tesisnya menyebutkan bahwa unsur people dalam mematuhi aturan dan prosedur merupakan poin penting dalam pengoptimalan mitigasi risiko TI.

Mengingat bahwa TI merupakan aset penting bagi organisasi dalam mencapai tujuannya, maka harus dikelola secara efektif agar penggunaannya menjadi optimal dan risiko yang timbul dapat dimitigasi. Sebagai upaya menjaga kualitas mutu manajemen dalam mempertahankan sertifikat ISO 9001, diperlukan upaya-upaya manajemen risiko TI untuk mengatasi risiko yang mungkin terjadi. Upaya manajemen risiko IT juga dimaksudkan untuk mengoptimalkan pelayanan EduManage. Manajemen risiko dapat memberikan pertimbangan dengan memperhatikan segala bentuk ketidakpastian dan tindakan yang harus diambil guna menangani berbagai risiko tersebut (Harahap, 2014). Paper ini menyajikan

studi kasus tentang permasalahan manajemen risiko TI pada layanan EduManage di USB.

\section{Latar Belakang Masalah}


Berdasarkan yang telah diungkapkan sebelumnya, paper ini memiliki tujuan untuk memberikan rekomendasi mitigasi risiko TI pada tata kelola layanan Edumanage di USB. Adapun beberapa kasus yang menjadi latar belakang permasalahan adalah sebagai berikut:

a. Sasaran mutu Universitas Setia Budi (USB) yang menuntut pencapaian layanan akademik yang tepat waktu dalam pelaporan melalui sistem PDPTFeeder Dikti. Untuk memenuhi sasaran mutu yang telah ditetapkan terdapat risiko TI, salah satunya adalah ketika USB kurang patuh dalam melaporkan nomor ijazah pada Feeder Dikti. Pemerintah melalui Kopertis Wilayah VI telah melakukan sosialisasi untuk input data nomor ijazah pada Feeder Dikti, namun USB tidak melakukannya dikarenakan EduManage belum memiliki menu untuk generate nomor ijazah. USB baru memulai menertibkan input data nomor ijazah ketika pemerintah memberlakukan program penelusuran nomor ijazah.

b. Pada tahun 2015, komputer server dimana EduManage ditempatkan mengalami kerusakan komponen power supply. Ketiadaan perangkat server cadangan menyebabkan layanan akademik sempat terhenti selama +/- 4 hari. Selama itu, seluruh SDM Sistem Informasi dikerahkan untuk sesegera mungkin memulihkan sistem EduManage. Terhentinya layanan akademik di USB merupakan akibat dari terjadinya risiko TI yang paling tinggi.

c. EduManage mulai digunakan untuk pelayanan akademik oleh BAA USB pada tahun 2013, kemudian pada tahun 2017, terjadi perubahan kebijakan/ aturan akademik berupa penyesuaian kurikulum. Salah satu dampak dari penyesuaian tersebut adalah perubahan jumlah pertemuan dalam satu semester, perubahan jumlah ujian dan komponen input nilai. Karena EduManage merupakan sistem yang dikembangkan pihak ketiga, perubahan sistem seperti ini merupakan risiko TI skala besar.

d. Seiring berjalannya waktu, USB melakukan penyesuaian organisasi. Pada tahun 2017 terjadi pergantian kepala Bagian Sistem Informasi dan sekaligus berkurangnya staf Sistem Informasi dari 3 orang personel menjadi 2 orang. Penyesuaian organisasi ini juga salah satu contoh kejadian yang memiliki dampak risiko TI terhadap layanan EduManage.

Selain kasus diatas, dari data historis laporan kegiatan registrasi dan data keluhan pelanggan dari bagian sistem informasi diperoleh beberapa kasus/keluhan pelanggan lain yang terjadi, yaitu: keterlambatan upload nilai oleh dosen, keterlambatan input KRS, kesalahan input KRS, data input KRS ada yang hilang, terlalu banyak menu di user interface (aplikasi kurang user friendly)

Berbagai permasalahan yang pernah terjadi menjadi kendala yang dalam operasional EduManage. Bahkan permasalahan tersebut pernah berakibat pelayanan akademik terhenti selama 4 hari. Dikarenakan saat ini tidak ada proses akademik yang masih dikerjakan secara manual, maka pengelolaan manajemen risiko TI yang tepat sangat diperlukan. 


\section{METODE PENELITIAN}

Terdapat banyak metode dan alat dalam manajemen risiko. Penelitian ini menggunakan kerangka pikir ISO 9001:2015, ISO 31010:2009 dan Failure Mode and Effect Analysis (FMEA). ISO 9001:2015 adalah framework Sistem Manajemen Mutu dengan pendekatan baru/ pola fikir berbasis risiko (Hadisaputra dan Kusumah, 2017). Sementara ISO 31010:2009 adalah risk assessment techniques sebagai standar pendukung ISO 31000 berupa teknik sistematis untuk menilai/melakukan asesmen risiko (ISO, 2009). Sedangkan FMEA merupakan teknik digunakan untuk mengidentifikasi (Hadisaputra dan Kusumah, 2017):

1. Semua potensi model kegagalan terhadap bermacam bagian suatu sistem (satu model kegagalan adalah apa yang diamati gagal atau tampil tidak secara benar).

2. Dampak dari kegagalan-kegagalan ini bisa jadi dimiliki sistem.

3. Mekanisme kegagalan

4. Bagaimana menghindari kegagalan, dan/atau memitigasi dampak kegagalan pada sistem.

Gambar 1 memperlihatkan tahapan - tahapan yang dilakukan pada penelitian ini. Penelitian dimulai dengan pengumpulan data gangguan TI yang menyebabkan layanan EduManage menjadi terhenti. Data yang diteliti merupakan data historis tiga tahun terakhir. Berikutnya, tahapan risk assessment dengan menggunakan kerangka pikir ISO 9001:2015, ISO 31010:2009 dan Failure Mode and Effect Analysis (FMEA). Framework ISO 9001 dan ISO 31010 digunakan untuk melakukan identifikasi risiko yang ada pada layanan EduManage. Identifikasi risiko juga dilakukan dengan membandingkan layanan IT yang berlangsung pada EduManage terhadap sasaran mutu USB yang telah ditetapkan. Tahapan selanjutnya adalah melakukan analisis risiko yang telah teridentifikasi dengan alat bantu FMEA. 


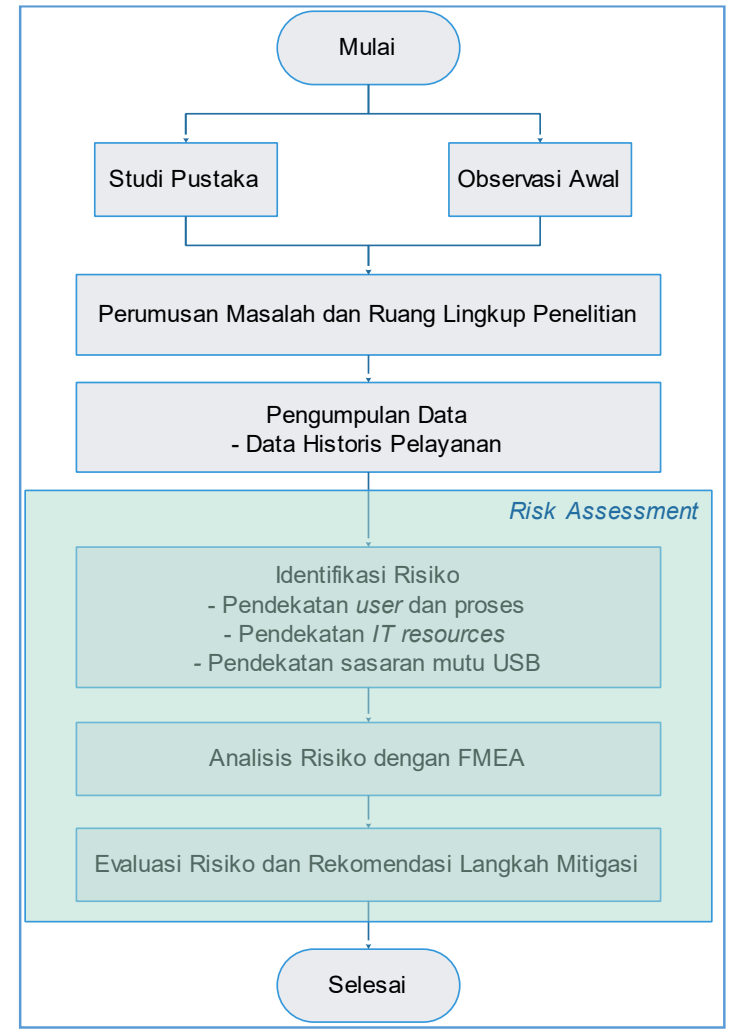

Gambar 1. Flowchart penelitian

\section{HASIL DAN PEMBAHASAN}

Dalam operasional EduManage selama ini, ada banyak risiko TI, baik itu risiko internal maupun risiko eksternal. Tabel 1 berikut memperlihatkan resiko TI yang dapat terjadi pada layanan akademik EduManage di USB.

Tabel 1. Identifikasi Risiko IT pada layanan EduManage di USB dengan pendekatan IT Resources

\begin{tabular}{llll}
\hline No & IT Resources & & \multicolumn{1}{c}{ Risiko TI } \\
\hline 1 & Software & - & Aplikasi terhenti karena kendala teknis \\
& & - & Aplikasi terhenti karena kendala jaringan \\
& & Aplikasi rusak \\
& & - & Database rusak \\
& & - & Serangan virus \\
& & - & Cyber attack \\
\hline 2. & Hardware & - & Perangkat keras server rusak \\
& & - & Perangkat jaringan rusak \\
& & - & Cyber attack \\
\hline
\end{tabular}




\begin{tabular}{lll}
\hline 3. & People & ketidak patuhan user terhadap jadwal waktu input jadwal, \\
& & mata kuliah, nilai \\
& & ketidak pahaman aturan/prosedur di Edumanage (terjadi \\
& & karena ada pergantian ketua progdi) \\
& & Ketelitian dan sikap aware saat input data \\
\hline $4 . \quad$ Pendukung & - & Gangguan listrik \\
& & Gangguan pada provider internet yang mengakibatkan \\
& & layanan EduManage tidak dapat diakses \\
\hline
\end{tabular}

Tabel 2. Identifikasi Risiko IT pada Layanan Edumanage di USB dengan Pendekatan User dan Proses

\begin{tabular}{|c|c|c|c|c|}
\hline NO & PENGGUNA & PROSES & ISU / HARAPAN & RISIKO \\
\hline & & nencorian informaci & kecepatan akses & kelambatan akses \\
\hline & & pencantan mimomatast & kejelasan informasi & informasi tidak jelas \\
\hline & & & kecepatan akses & kelambatan akses \\
\hline & & & & keterlambatan input krs \\
\hline & & & ketenatan innut & $\begin{array}{l}\text { mahasiswa salah input } \\
\text { krs }\end{array}$ \\
\hline & & & Ketepatan inpul & kelebihan input krs \\
\hline & & input krs & & $\begin{array}{l}\text { mahasiswa kekurangan } \\
\text { input mata kuliah }\end{array}$ \\
\hline & & & keamanan data & $\begin{array}{l}\text { kehilangan data mata } \\
\text { kuliah yang sudah } \\
\text { diinput }\end{array}$ \\
\hline & & & reliabilitas sistem & server down \\
\hline & & & informasi & bug dalam program \\
\hline & & & keakuratan data & bug dalam program \\
\hline & & cetak krs & $\begin{array}{l}\text { kesesuaian format } \\
\text { dengan kebutuhan }\end{array}$ & $\begin{array}{l}\text { perubahan kebutuhan } \\
\text { user }\end{array}$ \\
\hline & & & & $\begin{array}{l}\text { kurangnya jumlah } \\
\text { pengambilan sks mata } \\
\text { kuliah }\end{array}$ \\
\hline & & cetak khs dan transkrip & keakuratan data & $\begin{array}{l}\text { kelebihan jumlah } \\
\text { pengambilan sks mata } \\
\text { kuliah }\end{array}$ \\
\hline & & & & $\begin{array}{l}\text { salah pengambilan } \\
\text { mata kuliah }\end{array}$ \\
\hline 1 & & & $\begin{array}{l}\text { kesesuaian format } \\
\text { dengan kebutuhan }\end{array}$ & $\begin{array}{l}\text { ketidak sesuaian format } \\
\text { dengan kebutuhan }\end{array}$ \\
\hline \multirow[b]{3}{*}{2} & \multirow[b]{3}{*}{ dosen } & \multirow{2}{*}{ pencarian informasi } & kecepatan akses & kelambatan akses \\
\hline & & & kejelasan informasi & informasi tidak jelas \\
\hline & & download form nilai & $\begin{array}{l}\text { kemudahan proses } \\
\text { download }\end{array}$ & $\begin{array}{l}\text { prosedur download } \\
\text { yang kurang } \\
\text { memudahkan user }\end{array}$ \\
\hline
\end{tabular}

Vol. 7 - No. 1; November 2018 
Tekinfo -- Jurnal IImiah Teknik Industri dan Informasi -- 53

\begin{tabular}{|c|c|c|c|c|}
\hline NO & PENGGUNA & PROSES & ISU / HARAPAN & RISIKO \\
\hline & & & $\begin{array}{l}\text { kesesuaian format } \\
\text { dengan kebutuhan (uts- } \\
\text { uas, ukad) }\end{array}$ & $\begin{array}{l}\text { format nilai yang tidak } \\
\text { sesuai kebutuhan } \\
\text { karena perubahan } \\
\text { kebijakan akademik }\end{array}$ \\
\hline & & $\begin{array}{l}\text { upload nilai mata } \\
\text { kuliah }\end{array}$ & $\begin{array}{l}\text { ketepatan waktu upload } \\
\text { nilai }\end{array}$ & keterlambatan upload \\
\hline & & & $\begin{array}{l}\text { kemudahan proses } \\
\text { upload }\end{array}$ & kompatibilitas program \\
\hline & & approval krs oleh & $\begin{array}{l}\text { kemudahan proses } \\
\text { approval }\end{array}$ & bug dalam program \\
\hline & & dosen pa & $\begin{array}{l}\text { ketepatan waktu proses } \\
\text { approval }\end{array}$ & $\begin{array}{l}\text { keterlambatan approval } \\
\text { krs oleh dosen pa }\end{array}$ \\
\hline \multirow{11}{*}{3} & \multirow{11}{*}{$\begin{array}{l}\text { ketua program } \\
\text { studi }\end{array}$} & \multirow{2}{*}{$\begin{array}{l}\text { pencarian informasi } \\
\text { mahasiswa }\end{array}$} & $\begin{array}{l}\text { kesesuaian informasi } \\
\text { dengan kebutuhan }\end{array}$ & $\begin{array}{l}\text { adanya kebutuhan yang } \\
\text { belum terwadahi dalam } \\
\text { program }\end{array}$ \\
\hline & & & $\begin{array}{l}\text { kemudahan proses } \\
\text { pencarian informasi }\end{array}$ & $\begin{array}{l}\text { prosedur pencarian } \\
\text { yang kurang } \\
\text { memudahkan user }\end{array}$ \\
\hline & & \multirow{2}{*}{$\begin{array}{l}\text { monitoring approval } \\
\text { dosen pa }\end{array}$} & $\begin{array}{l}\text { kesesuaian informasi } \\
\text { dengan kebutuhan }\end{array}$ & $\begin{array}{l}\text { kaprogdi tidak bisa } \\
\text { mengakses dosen pa } \\
\text { diluar homebase } \\
\text { progdinya }\end{array}$ \\
\hline & & & $\begin{array}{l}\text { kemudahan proses } \\
\text { pencarian informasi }\end{array}$ & $\begin{array}{l}\text { prosedur pencarian } \\
\text { yang kurang } \\
\text { memudahkan user }\end{array}$ \\
\hline & & monitoring input nilai & $\begin{array}{l}\text { kemudahan proses } \\
\text { pencarian informasi }\end{array}$ & $\begin{array}{l}\text { prosedur pencarian } \\
\text { yang kurang } \\
\text { memudahkan user }\end{array}$ \\
\hline & & \multirow{4}{*}{ input mata kuliah } & $\begin{array}{l}\text { kemudahan proses } \\
\text { input mata kuliah }\end{array}$ & $\begin{array}{l}\text { prosedur input yang } \\
\text { kurang memudahkan } \\
\text { user }\end{array}$ \\
\hline & & & $\begin{array}{l}\text { ketepatan waktu proses } \\
\text { input mata kuliah }\end{array}$ & keterlambatan input \\
\hline & & & $\begin{array}{l}\text { keakuratan data yang } \\
\text { diinput (kode mata } \\
\text { kuliah, dsb) }\end{array}$ & $\begin{array}{l}\text { salah input kode mata } \\
\text { kuliah }\end{array}$ \\
\hline & & & $\begin{array}{l}\text { kelengkapan data yang } \\
\text { diinput (mata kuliah } \\
\text { yang dibuka) }\end{array}$ & $\begin{array}{l}\text { mata kuliah yang } \\
\text { diinput kurang }\end{array}$ \\
\hline & & \multirow{2}{*}{ input jadwal } & $\begin{array}{l}\text { kemudahan proses } \\
\text { input jadwal kuliah }\end{array}$ & $\begin{array}{l}\text { prosedur input yang } \\
\text { kurang memudahkan } \\
\text { user }\end{array}$ \\
\hline & & & $\begin{array}{l}\text { ketepatan waktu proses } \\
\text { input jadwal kuliah }\end{array}$ & $\begin{array}{l}\text { keterlambatan input } \\
\text { jadwal kuliah }\end{array}$ \\
\hline \multirow[t]{2}{*}{4} & \multirow[t]{2}{*}{$\begin{array}{l}\text { administrator } \\
\text { akademik }\end{array}$} & pencarian informasi & $\begin{array}{l}\text { kesesuaian informasi } \\
\text { dengan kebutuhan }\end{array}$ & $\begin{array}{l}\text { adanya kebutuhan yang } \\
\text { belum terwadahi dalam } \\
\text { program }\end{array}$ \\
\hline & & input data awal & keakuratan data & ada kesalahan data dari \\
\hline
\end{tabular}




\begin{tabular}{|c|c|c|c|c|}
\hline NO & PENGGUNA & PROSES & ISU / HARAPAN & RISIKO \\
\hline & & semester & & program pmb \\
\hline & & \multirow[b]{2}{*}{$\begin{array}{l}\text { input data akhir } \\
\text { semester }\end{array}$} & \multirow{2}{*}{$\begin{array}{l}\text { kelengkapan data yang } \\
\text { diinputkan }\end{array}$} & data nilai tidak lengkap \\
\hline & & & & $\begin{array}{l}\text { data tidak up to date / } \\
\text { database sampah }\end{array}$ \\
\hline & & \multirow{4}{*}{ sinkron data ke feeder } & \multirow{4}{*}{$\begin{array}{l}\text { kecepatan dan } \\
\text { kemudahan proses } \\
\text { sinkron }\end{array}$} & error program \\
\hline & & & & server down \\
\hline & & & & $\begin{array}{l}\text { perubahan aplikasi } \\
\text { feeder pddikti }\end{array}$ \\
\hline & & & & $\begin{array}{l}\text { belum ada web service } \\
\text { yang membantu } \\
\text { snkronisasi, proses } \\
\text { manual }\end{array}$ \\
\hline & & \multirow[b]{2}{*}{ cetak form presensi } & $\begin{array}{l}\text { ketepatan waktu } \\
\text { pencetakan }\end{array}$ & $\begin{array}{l}\text { presensi tidak ready } \\
\text { tepat waktu }\end{array}$ \\
\hline & & & ketepatan data & $\begin{array}{l}\text { data mahasiswa di } \\
\text { presensi tidak lengkap, } \\
\text { karena proses approval } \\
\text { bag keuangan }\end{array}$ \\
\hline & & \multirow[b]{3}{*}{ cetak form pantauan } & \multirow[b]{3}{*}{$\begin{array}{l}\text { ketepatan waktu } \\
\text { pencetakan }\end{array}$} & $\begin{array}{l}\text { form pantauan tidak } \\
\text { ready tepat waktu }\end{array}$ \\
\hline & & & & $\begin{array}{l}\text { nama dosen yang } \\
\text { tertera tidak valid }\end{array}$ \\
\hline & & & & $\begin{array}{l}\text { perubahan kebutuhan } \\
\text { karena kebijakan mata } \\
\text { kuliah gabungan teori } \\
\text { praktek }\end{array}$ \\
\hline & & \multirow[b]{2}{*}{ cetak form nilai (dpun) } & $\begin{array}{l}\text { ketepatan waktu } \\
\text { pencetakan }\end{array}$ & $\begin{array}{l}\text { form nilai (dpun) tidak } \\
\text { ready tepat waktu }\end{array}$ \\
\hline & & & $\begin{array}{l}\text { kesesuaian format } \\
\text { dengan yang } \\
\text { dibutuhkan }\end{array}$ & $\begin{array}{l}\text { beda kebutuhan format } \\
\text { antar fakultas }\end{array}$ \\
\hline & & \multirow[t]{2}{*}{ cetak form nilai (khs) } & kelengkapan data nilai & $\begin{array}{l}\text { nilai dalam khs } \\
\text { mahasiswa tidak } \\
\text { lengkap }\end{array}$ \\
\hline & & & $\begin{array}{l}\text { ketepatan waktu } \\
\text { pencetakan }\end{array}$ & $\begin{array}{l}\text { khs terlambat } \\
\text { terdistribusi }\end{array}$ \\
\hline
\end{tabular}

Setelah keseluruhan resiko yang telah terindentifikasi, proses penilaian resiko dilanjutkan dengan merekap dan meresume keseluruhan resiko dan mengevaluasinya dengan FMEA. Keseluruhan 68 resiko yang teridentifikasi dapat dicompress menjadi 37 resiko. Dari masing-masing resiko dinilai tingkat kemungkinan terjadinya/ likely hood (L), tingkat keparahannya/ severity (S), tingkat kegagalan deteksinya/ detection (D) sesuai dengan tabel 3 sd 5, untuk selanjutnya dihitung Tingkat Prioritas Resikonya/ Risk Priority Number (RPN). 
Tabel 3. Kriteria Kemungkinan Terjadinya (Likely Hood) Risiko

\begin{tabular}{cccl}
\hline No. & Ranking & Bobot & \multicolumn{1}{c}{ Penjelasan } \\
\hline 1 & Tinggi & 3 & sering terjadi $(>2 \mathrm{x}$ dalam 1 semester) \\
\hline 2 & Sedang & 2 & kadang terjadi (1-2x dalam 1 semester) \\
\hline 3 & Rendah & 1 & jarang terjadi \\
\hline
\end{tabular}

Tabel 4. Kriteria Tingkat Keparahan (Severity) Risiko

\begin{tabular}{cccl}
\hline No. & Ranking & Bobot & \multicolumn{1}{c}{ Penjelasan } \\
\hline 1 & Tinggi & 3 & $\begin{array}{l}\text { pelayanan akademik terhenti dan harus menunggu lama } \\
\text { karena terkait dengan anggaran dan pihak eksternal }\end{array}$ \\
\hline 2 & Sedang & 2 & $\begin{array}{l}\text { pelayanan akademik terhenti sebentar, dan bisa diperbaiki } \\
\text { tanpa terkait anggaran dan pihak eksternal }\end{array}$ \\
\hline 3 & Rendah & 1 & $\begin{array}{l}\text { pelayanan akademik terganggu/ tidak sesuai target/ berjalan } \\
\text { lebih lama, namun tetap bisa jalan }\end{array}$ \\
\hline
\end{tabular}

Tabel 5. Kriteria Kegagalan Deteksi (Detection) Risiko

\begin{tabular}{cccl}
\hline No. & Ranking & Bobot & \multicolumn{1}{c}{ Penjelasan } \\
\hline 1 & Tinggi & 3 & tidak terdeteksi sebelum terjadi \\
\hline 2 & Sedang & 2 & $\begin{array}{l}\text { penyebab resiko mampu terdeteksi dengan menggunakan alat } \\
\text { atau sistem }\end{array}$ \\
\hline 3 & Rendah & 1 & $\begin{array}{l}\text { penyebab resiko mampu terdeteksi sebelum terjadi tanpa alat } \\
\text { atau sistem }\end{array}$ \\
\hline
\end{tabular}



Tabel 6. Hasil Analisa Resiko dengan FMEA untuk Tingkat Prioritas Penanganan Resiko Sedang dan Tinggi

\begin{tabular}{|c|c|c|c|c|c|c|c|c|c|}
\hline No. & Risiko & Penyebab Risiko & $(\mathrm{L})^{*}$ & $(\mathrm{~S})^{*}$ & (D)* & (RPN)* & $\begin{array}{l}\text { Pengendalian } \\
\text { Proses Saat Ini }\end{array}$ & $\begin{array}{c}\text { Rekomendasi Mitigasi terhadap } \\
\text { Resiko }\end{array}$ & $\begin{array}{c}\text { Penanggung } \\
\text { Jawab }\end{array}$ \\
\hline 1 & $\begin{array}{l}\text { EduManage terhenti dan } \\
\text { tidak dapat diakses karena } \\
\text { kendala jaringan }\end{array}$ & $\begin{array}{l}\text { akses internet } \\
\text { terputus, mati listrik }\end{array}$ & 2 & 3 & 3 & 18 & $\begin{array}{l}\text { menyediakan } \\
\text { UPS }\end{array}$ & $\begin{array}{l}\text { pengadaan UPS di server dengan } \\
\text { kapasitas yang mecukupi dan UPS } \\
\text { portabel di setiap node jaringan }\end{array}$ & BAA\&SI \\
\hline 2 & Database rusak & serangan virus & 2 & 3 & 3 & 18 & $\begin{array}{l}\text { backup } \\
\text { database }\end{array}$ & $\begin{array}{l}\text { Back up program yang terencana, dan } \\
\text { konsisten beserta sistem controllingnya }\end{array}$ & BAA\&SI \\
\hline 3 & $\begin{array}{l}\text { data mahasiswa tidak di } \\
\text { up-date (misal mahasiswa } \\
\text { lulus namun tidak diupdate } \\
\text { telah lulus) }\end{array}$ & $\begin{array}{l}\text { input/ perubahan data } \\
\text { tidak dilakukan secara } \\
\text { menyeluruh } \\
\text { (perubahan nilai, } \\
\text { perubahan status } \\
\text { mahasiswa) }\end{array}$ & 2 & 3 & 2 & 12 & $\begin{array}{l}\text { identifikasi } \\
\text { kekurangan } \\
\text { data, diperbaiki } \\
\text { satu demi satu }\end{array}$ & $\begin{array}{l}\text { perlu dibuat SOP pengecekan } \\
\text { kelengkapan data di setiap akhir } \\
\text { semester (bulan Februari dan Agustus) } \\
\text { sebelum masa pelaporan PDDIKTI dan } \\
\text { bisa digunakan bahan untuk monitoring } \\
\text { studi mhs tiap akhir semester }\end{array}$ & BAA\&SI \\
\hline 4 & $\begin{array}{l}\text { Kesalahan saat input KRS } \\
\text { (salah pilih mata kuliah, } \\
\text { kurang atau kelebihan } \\
\text { input mata kuliah) }\end{array}$ & $\begin{array}{l}\text { Ketelitian dan sikap } \\
\text { peduli mahasiswa saat } \\
\text { input KRS }\end{array}$ & 2 & 3 & 2 & 12 & - & $\begin{array}{l}\text { pembuatan flow chart proses input KRS, } \\
\text { yang simpel, jelas dan memudahkan } \\
\text { user untuk memahami }\end{array}$ & BAA\&SI \\
\hline 5 & $\begin{array}{l}\text { Jadwal input KRS yang } \\
\text { telah ditetapkan dilanggar }\end{array}$ & $\begin{array}{l}\text { ketidak patuhan } \\
\text { mahasiswa terhadap } \\
\text { jadwal input KRS }\end{array}$ & 3 & 2 & 2 & 12 & $\begin{array}{l}\text { perpanjangan } \\
\text { waktu input } \\
\text { KRS }\end{array}$ & $\begin{array}{l}\text { sosialisasi dan notifikasi jadwal input } \\
\text { lewat bbrp media (web, wa, dll) }\end{array}$ & BAA\&SI \\
\hline 6 & $\begin{array}{l}\text { Jadwal upload nilai yang } \\
\text { telah ditetapkan tidak } \\
\text { dipatuhi oleh dosen }\end{array}$ & $\begin{array}{l}\text { ketidak patuhan dosen } \\
\text { terhadap jadwal } \\
\text { upload nilai }\end{array}$ & 3 & 2 & 2 & 12 & - & $\begin{array}{l}\text { sosialisasi dan notifikasi jadwal } \\
\text { akademik lewat bbrp media (web, wa, } \\
\text { dll) }\end{array}$ & BAA\&SI \\
\hline 7 & $\begin{array}{l}\text { keterlambatan approval } \\
\text { KRS oleh dosen PA }\end{array}$ & $\begin{array}{l}\text { mahasiswa tidak } \\
\text { peduli dengan } \\
\text { prosedur bimbingan } \\
\text { PA, dosen PA tidak } \\
\text { peduli dengan jadwal } \\
\text { approval KRS yang } \\
\text { telah ditetapkan } \\
\text { BAASI }\end{array}$ & 3 & 2 & 2 & 12 & - & $\begin{array}{l}\text { notifikasi bagi dosen PA mengenai } \\
\text { approval KRS }\end{array}$ & BAA\&SI \\
\hline
\end{tabular}


54 -- Tekinfo -- Jurnal IImiah Teknik Industri dan Informasi

\begin{tabular}{|c|c|c|c|c|c|c|c|c|c|}
\hline No. & Risiko & Penyebab Risiko & $(\mathrm{L})^{*}$ & $(\mathbf{S})^{*}$ & (D)* & $(\mathrm{RPN}) *$ & $\begin{array}{l}\text { Pengendalian } \\
\text { Proses Saat Ini }\end{array}$ & $\begin{array}{c}\text { Rekomendasi Mitigasi terhadap } \\
\text { Resiko }\end{array}$ & $\begin{array}{c}\text { Penanggung } \\
\text { Jawab }\end{array}$ \\
\hline 8 & $\begin{array}{l}\text { nilai dalam KHS } \\
\text { mahasiswa tidak lengkap }\end{array}$ & $\begin{array}{l}\text { ketidak patuhan dosen } \\
\text { terhadap jadwal } \\
\text { upload nilai }\end{array}$ & 3 & 2 & 2 & 12 & - & $\begin{array}{l}\text { sosialisasi dan notifikasi jadwal } \\
\text { akademik lewat bbrp media (web, wa, } \\
\text { dll) }\end{array}$ & BAA\&SI \\
\hline 9 & $\begin{array}{l}\text { kesalahan input dari } \\
\text { progdi (kode mata kuliah) }\end{array}$ & $\begin{array}{l}\text { Kaprogdi tidak aware } \\
\text { akan makna kode } \\
\text { mata kuliah }\end{array}$ & 3 & 2 & 2 & 12 & - & $\begin{array}{l}\text { pembuatan flow chart/ manual proses } \\
\text { input mata kuliah yang simpel, jelas dan } \\
\text { memudahkan user untuk memahami }\end{array}$ & BAA\&SI \\
\hline 10 & $\begin{array}{l}\text { Aplikasi EduManage } \\
\text { rusak/ error }\end{array}$ & $\begin{array}{l}\text { serangan hacker atau } \\
\text { serangan virus }\end{array}$ & 1 & 3 & 3 & 9 & $\begin{array}{l}\text { Backup } \\
\text { program dan } \\
\text { database } \\
\text { EduManage } \\
\end{array}$ & $\begin{array}{l}\text { SOP Backup, konsistensi dan sistem } \\
\text { controlling }\end{array}$ & BAA\&SI \\
\hline 11 & Cyber attack & $\begin{array}{l}\text { keamanan jaringan } \\
\text { kurang kuat }\end{array}$ & 1 & 3 & 3 & 9 & - & $\begin{array}{l}\text { Back up program yang terencana, dan } \\
\text { konsisten beserta sistem controllingnya }\end{array}$ & BAA\&SI \\
\hline 12 & Serangan virus & $\begin{array}{l}\text { maintenance } \\
\text { keamanan jaringan } \\
\text { kurang }\end{array}$ & 1 & 3 & 3 & 9 & - & $\begin{array}{l}\text { Back up program yang terencana, dan } \\
\text { konsisten beserta sistem controllingnya }\end{array}$ & BAA\&SI \\
\hline 13 & $\begin{array}{l}\text { Sistem Operasi server } \\
\text { rusak }\end{array}$ & $\begin{array}{l}\text { virus, ketidak stabilan } \\
\text { listrik }\end{array}$ & 1 & 3 & 3 & 9 & - & $\begin{array}{l}\text { Back up program yang terencana, dan } \\
\text { konsisten beserta sistem controllingnya }\end{array}$ & BAA\&SI \\
\hline
\end{tabular}

Keterangan tabel:

L: $\quad$ Kemungkinan Terjadi / Likely Hood

S: $\quad$ Tingkat Keparahan / Severity

D: Deteksi/ Detect

RPN: Risk Priority Number 
Untuk mengoptimalkan proses mitigasi berkaitan dengan terbatasnya resources, maka dari 37 resiko yang ada, diambil 13 resiko dengan RPN 9 keatas, yang bisa dikategorikan sebagai resiko dengan tingkat prioritas sedang dan tinggi seperti pada tabel 6 . Untuk memetakan ulang resiko dan langkah mitigasinya, 13 resiko dan langkah mitigasinya bisa dikelompokkan seperti pada tabel 7.

Tabel 7. Pengelompokkan Resiko dan Rekomendasi Langkah Mitigasi

\begin{tabular}{lll}
\hline No. & \multicolumn{1}{c}{ Resiko } & \multicolumn{1}{c}{ Rekomendasi Langkah Mitigasi } \\
\hline 1. & $\begin{array}{l}\text { Program terhenti, Sistem Operasi } \\
\text { rusak karena masalah listrik }\end{array}$ & $\begin{array}{l}\text { pengadaan UPS di server dengan kapasitas yang } \\
\text { mencukupi dan UPS portabel di setiap node } \\
\text { jaringan }\end{array}$ \\
\hline 2. $\quad \begin{array}{l}\text { Database, aplikasi, sistem operasi } \\
\text { server rusak karena serangan } \\
\text { virus dan serangan hacker }\end{array}$ & $\begin{array}{l}\text { Pembuatan SOP Backup baik program maupun } \\
\text { database, konsistensi pelaksanaan dan sistem } \\
\text { controlling }\end{array}$ \\
\hline & $\begin{array}{l}\text { Kesalahan input data (kode mata } \\
\text { kuliah oleh Ka Progdi, input KRS } \\
\text { oleh mahasiswa) }\end{array}$ & $\begin{array}{l}\text { Pembuatan flow chart proses : } \\
\text { - input KRS untuk mahasiswa mata kuliah untuk Kaprogdi, }\end{array}$ \\
\hline & $\begin{array}{l}\text { Data mahasiswa tidak di up-date } \\
\text { (perubahan status mahasiswa, } \\
\text { perbaikan nilai) karena input data } \\
\text { atau perbaikan data tidak } \\
\text { dilakukan secara menyeluruh }\end{array}$ & $\begin{array}{l}\text { Pembuatan SOP pengecekan kelengkapan data di } \\
\text { setiap akhir semester (bulan Februari dan } \\
\text { Agustus) sebelum masa pelaporan PDDIKTI dan } \\
\text { bisa digunakan bahan untuk monitoring studi } \\
\text { mahasiswa tiap akhir semester }\end{array}$ \\
\hline $\begin{array}{l}\text { Keterlambatan input data (nilai } \\
\text { oleh dosen pengampu, KRS oleh } \\
\text { mahasiswa, approval KRS oleh } \\
\text { dosen PA) }\end{array}$ & $\begin{array}{l}\text { sosialisasi dan notifikasi jadwal input nilai, KRS } \\
\text { mahasiswa dan approval KRS lewat beberapa } \\
\text { media (web, wa, dll) }\end{array}$ \\
\hline
\end{tabular}

\section{KESIMPULAN}

Dari proses analisis manajemen resiko pada sistem pelayanan akademik Edumanage di Universitas Setia Budi diperoleh 37 resiko yang mungkin terjadi, dengan 13 resiko yang berkategori resiko sedang hingga tinggi, sehingga direkomendasikan untuk mendapatkan prioritas mitigasi. Adapun rekomendasi langkah mitigasi resiko untuk 13 resiko yang diprioritaskan bisa terbagi menjadi 2 kategori, yaitu:

1) secara fisik, yaitu pengadaan UPS di server dengan kapasitas yang mencukupi dan UPS portabel di setiap node jaringan

2) secara administratif, yaitu: 
a. Pembuatan SOP Backup program maupun database, konsistensi pelaksanaan dan sistem controlling.

b. Pembuatan flowchart proses, input KRS untuk mahasiswa, input mata kuliah untuk Kaprogdi yang simpel, jelas dan memudahkan user untuk memahami

c. Pembuatan SOP pengecekan kelengkapan data di setiap akhir semester (bulan Februari dan Agustus) sebelum masa pelaporan PDDIKTI dan bisa digunakan bahan untuk monitoring studi mahasiswa tiap akhir semester

d. sosialisasi dan notifikasi jadwal input nilai, KRS mahasiswa dan approval KRS lewat beberapa media (web, wa, dll)

\section{SARAN}

Penelitian selanjutnya diharapkan bisa memperluas ruang lingkup, tidak hanya manajemen resiko pada pelayanan akademik dengan edu Manage, dan juga meliputi proses implementasi rekomendasi mitigasi resiko dan evaluasi, sehingga lebih komprehensif.

\section{DAFTAR PUSTAKA}

Angraini dan Pertiwi, I. D. (2017) “Analisa Pengelolaan Risiko Penerapan Teknologi Informasi Menggunakan ISO 31000,” Jurnal Ilmiah Rekayasa dan Manajemen Sistem Informasi, 3(2), hal. 70-76. Tersedia pada: http://ejournal.uin-suska.ac.id/index.php/RMSI/article/view/4317 (Diakses: 7 November 2018).

Bagye, W. (2015) "Analisis Tingkat Kematangan Sistem Informasi Akademik Menggunakan Framework COBIT 4.1 (Studi Kasus: STMIK Lombok),” Speed - Sentra Penelitian Engineering dan Edukasi, 8(1). doi: 10.3112/SPEED.V8I1.1382.

Darwis, D. dan Yuniarwati, . (2016) “Audit Tata Kelola Teknologi Informasi Menggunakan Framework COBIT 4.1 sebagai Upaya Peningkatan Keamanan Data pada Dinas Pendidikan dan Kebudayaan Kabupaten Pesawaran," EXPLORE. Pusat Studi Teknologi Informasi - Fakultas Ilmu Komputer Universitas Bandar Lampung, 7(1). Tersedia pada: http://jurnal.ubl.ac.id/index.php/explore/article/view/770 (Diakses: 19 Oktober 2018).

Hadisaputra, S. dan Kusumah, L. H. (2017) “Implementasi Manajemen Risiko Berbasis ISO 9001:2015 dan ISO 31010:2009 Pada Usaha Jasa Konsultasi dan Pelatihan Di PT BSU Penerapan Fault Tree Analysis (FTA) Dan Failure Mode And Effect Analysis (FMEA)," in Prosiding SENIATI. Malang: Institut Teknologi Nasional, hal. C49.1-12. Tersedia pada: 
http://ejournal.itn.ac.id/index.php/seniati/article/view/1040 (Diakses: 11 Oktober 2018).

Harahap, N. S. (2014) "Manajemen Risiko Teknologi Informasi Menggunakan Framework ISO 31000 (Studi Kasus: Sistem Infrastruktur TI Telkom Indonesia)," Jurnal Sains dan Teknologi Industri, 9(1), hal. 52-66. Tersedia pada: http://ejournal.uin-suska.ac.id/index.php/sitekin/article/view/607 (Diakses: 7 November 2018).

IEC 31010:2009, Risk management — Risk assessment techniques (2009) Iso.Org. Tersedia pada: https://www.iso.org/obp/ui/\#iso:std:iec:31010:ed-1:v1:en (Diakses: 10 November 2018).

Putra, I. G. L. A. R. (2015) Evaluasi Tata Kelola Teknologi Informasi Berbasis COBIT 5 Dalam Pelayanan Sistem Informasi Akademik Di Universitas Pendidikan Ganesha. Universitas Atmajaya Yogyakarta. Tersedia pada: http://e-journal.uajy.ac.id/7554/ (Diakses: 4 November 2018). 